\title{
ДОСЛІДЖЕННЯ ЗМІН РЕПАРАТИВНОЇ ЗДАТНОСТІ ШКІРИ ПІСЛЯОПЕРАЦІЙНИХ РАН ЩУРІВ ІЗ СТРЕПТОЗОТОЦИНОВИМ ЦУКРОВИМ ДІАБЕТОМ
}

Дослідження змін репаративної здатності шкіри післяопераційних ран щурів із стрептозотоциновим цукровим діабетом

€. О. Лоза, Т. М. Гомелюк, І. Я. Криницька, М. І. Марущак

Тернопільський національний медичний університет імені І. Я. Горбачевського

Резюме. Цукровий діабет (ЦД) у всьому світі визнаний одним із найбільш важливих неінфрекційних захворювань. ЦД та його ускладнення є одними з найважливіших причин смертності, при цьому одним з важливих наслідків ЦД є порушення здатності до репарації.

Мета дослідження - виявити зміни репаративної здатності шкіри при різних способах закриття післяопераційних ран щурів за умов стрептозотоцинового цукрового діабету.

Матеріали і методи. Експериментальні дослідження проведено на 130 білих безпородних статевозрілих щурах-самцях, яких поділили на 4 групи: перша (30 тварин) - здорові, яким накладено вузлові шви на операційну рану; друга група (30 щурів) - здорові, яким для фріксації країв рани застосували шкірний клей; третя (30 тварин) - 3 цукровим діабетом, яким накладено вузлові шви на операційну рану; четверта група (30 щурів) - з цукровим діабетом, яким для фріксації країв рани застосували шкірний клей. Для контролю всі отримані результати порівнювали із показниками інтактних тварин (10 щурів).

Результати. Результати наших досліджень показують, що рановий процес призводить до зниження репаративної здатності шкіри на ранньому терміні спостереження. У віддаленому терміні спостереження у здорових групах щурів відбувається відновлення репаративної здатності дерми на відміну від груп щурів із стрептозотоциновим цукровим діабетом.

Висновки. Отримані результати свідчать про зниження репаративної здатності шкіри, зумовленої рановим процесом у щурів з експериментальним цукровим діабетом стосовно здорових щурів при застосуванні шкірного клею. При цьому застосування його $\epsilon$ еорективнішим для фрормування нормотрофрічного рубця за умов цукрового діабету, порівняно із накладанням вузлових швів для фріксації країв ран.

Ключові слова: репаративна здатність шкіри; оксидативний стрес; патологічний рубець; стрептозотоциновий діабет.
Study of changes of skin reparative ability of postoperative wounds in rats with streptozotocininduced diabetes

Ye. O. Loza, T. M. Homeliuk, I. Ya. Krynytska, M. I. Marushchak

I. Horbachevsky Ternopil National Medical University e-mail: marushchak@tdmu.edu.ua

Summary. Diabetes mellitus (DM) is recognized as one of the most important non-contagious diseases worldwide. Diabetes mellitus and its complications are one of the most important causes of death, and one of the important consequences of diabetes is impaired ability to repair.

The aim of the study - to identify changes in the reparative ability of the skin in rats with streptozotocininduced diabetes, where different ways of closing postoperative wounds were used.

Materials and Methods. Experimental studies were performed on 130 white outbred adult male rats, which were divided into 4 groups: Group I (30 rats) - healthy, nodal sutures were used for the wound closure; Group II (30 rats) healthy, skin glue was used for the wound closure; Group III (30 rats) - with diabetes mellitus, nodal sutures were used for the wound closure; Group IV (30 rats) - with diabetes mellitus, skin glue was used for the wound closure. For control, all the results were compared with those of intact animals (10 rats).

Results. Our research proves that the wound process leads to a decrease in the reparative ability of the skin at an early stage of observation. In the long-term follow-up, the reparative ability of the dermis in healthy groups of rats restore in contrast to groups of rats with streptozotocin diabetes.

Conclusion. The results show a decrease of the reparative ability of the skin, caused by wound healing in rats with experimental diabetic and in healthy rats where skin glue was used for the wound closure. However, the use of skin glue is more effective for the formation of normal scar in rats with diabetes, compared with the imposition of nodal sutures for the wound closure.

Key words: reparative ability of the skin; oxidative stress; pathological scar; streptozotocin-induced diabetes. 


\section{вСТУП}

Цукровий діабет (ЦД) у всьому світі визнаний одним 3 найбільш важливих неінфекційних захворювань, а також однією із найсерйозніших проблем охорони здоров'я XXI ст. [1, 2]. Необхідність профрілактики утворення патологічного рубцювання тканин після хірургічних втручань, травм, опіків було і залишається актуальним науково-практичним завданням [3-6]. Незважаючи на постійне удосконалення методів профрілактики і тактики післяопераційного ведення хворих, утворення грубих деформуючих рубців становить одну з серйозних проблем сучасної медицини.

ЦД та його ускладнення є одними з найважливіших причин смертності [7]. За даними ряду авторів, наявність ЦД пов'язана зі збільшенням смертності від інфекцій, серцево-судинних захворювань, інсульту, хронічних захворювань нирок, хронічних захворювань печінки та раку [8]. Як наслідок гіперглікемії у хворих на ЦД підвищений ризик розвитку супутніх захворювань [9], при цьому одним із важливих наслідків ЦД є порушення здатності до репарації [10].

Метою дослідження було виявити зміни репаративної здатності шкіри при різних способах закриття післяопераційних ран щурів за умов стрептозотоцинового цукрового діабету.

\section{МАТЕРІАЛИ I МЕТОДИ}

Експериментальні дослідження проведено на 130 білих безпородних статевозрілих щурах-самцях масою від 240 до 320 г, яких утримували в одному приміщенні віварію. Усіх тварин поділили на 4 експериментальні групи (табл. 1).

Для контролю усі отримані результати порівнювали із показниками інтактних тварин.

Моделювання цукрового діабету проводили стрептозотоцином («Sigma», США) (внутрішньочеревно - 65 мг/кг) з попереднім (за 15 хв) введенням нікотинаміду (інтраперитоніально - 230 мг/кг) тваринам третьої та першої груп. На тлі ожиріння, яке викликали шляхом 4-тижневого утримання тварин на високожировій дієті, розвиток ЦД 2 підтверджували шляхом визначення концентрації глюкози в крові з використанням глюкометра BAYER Contour Next (Німеччина).
Тваринам усіх груп (перша-четверта) під тіопенталовим наркозом (40 мг/кг маси щура) проводили повношарові прямолінійні розрізи довжиною 2 см у передньо-бічній ділянці живота. Для фріксація країв операційної рани тваринам першої та третьої експериментальних груп накладено вузлові шви ниткою «Vicryl 5/0» (ETHICON, Inc. a Johnson\&Johnson company (USA). Щурам другої та четвертої експериментальних груп фріксацію країв операційної рани здійснено шляхом нанесення шкірного клею «Dermabond» (ETHICON, Inc. a Johnson\&Johnson company (USA). Тварин виводили з експерименту на 3; 7; 28 доби після оперативного втручання під тіопенталовим наркозом (90 мг/кг маси щура). Peпаративну здатність дерми визначали за кількістю РНК і ДНК за методикою А. С. Спіріна у гомогенаті шкіри [11]. Статистичну обробку отриманих даних проведено стандартними методами варіаційної статистики з використанням пакета статистичних програм. Результати наведено як (M $\pm \mathrm{m})$, де $\mathrm{M}$ - ceреднє значення показника, $\mathrm{m}$ - стандартна похибка. Достовірність розбіжностей між дослідними показниками визначали за допомогою критерію Стьюдента [12].

\section{РЕЗУЛЬТАТИ Й ОБГОВОРЕННЯ}

Основи ДНК також дуже сприйнятливі до окиснення вільними радикалами, а переважним кінцевим продуктом цієї взаємодії є 8-гідрокси-2дезоксигуанозин. В результаті можуть виникнути мутації і делеції як в ядерній, так і в мітохондріальній ДНК. Мітохондріальна ДНК особливо схильна до окиснювального ушкодження через ії близькість до першого джерела вільних радикалів і недостатню відновну здатність, порівняно із ядерною ДНК. Ці окисні модисрікації призводять до фрункціональних змін у ферментних і структурних білках, які можуть чинити істотну фізіологічну дію [13].

На 3-ю добу після оперативного втручання у здорових щурів, яким для фріксації країв рани застосовували хірургічні нитки, вміст РНК зменшився на 22,6 \%, а ДНК - на $22 \%$, порівняно із рівнем інтактних тварин. У групі щурів, яким наносили біологічний клей, таке зниження становило 21,1\% (РНК) та 19,4 \% (ДНК) відповідно, що свідчить про

Таблиця 1. Поділ груп експериментальних тварин

\begin{tabular}{l|l|c}
\hline \multicolumn{1}{c|}{ Група } & \multicolumn{1}{c}{ Група спостережень } & Кількість тварин \\
\hline \multicolumn{1}{|l}{ Інтактні щури } & 30 \\
\hline Перша група & Здорові білі щури, яким накладено вузлові шви на операційну рану & 30 \\
\hline Друга група & $\begin{array}{l}\text { Здорові білі щури, яким фріксацію країв операційної рани здійснено } \\
\text { нанесенням шкірного клею }\end{array}$ & 30 \\
\hline Третя група & $\begin{array}{l}\text { Тварини з цукровим діабетом, яким накладено вузлові шви на опе- } \\
\text { раційну рану }\end{array}$ & 30 \\
\hline Четверта група & $\begin{array}{l}\text { Тварини з цукровим діабетом, яким ффіксацію країв операційної рани } \\
\text { здійснено нанесенням шкірного клею }\end{array}$ \\
\hline
\end{tabular}


зменшення репаративної здатності шкіри, зумовленої рановим процесом. У тварин із ЦД 2 також спостерігали зниження вмісту РНК та ДНК на 36,3 і $37,6 \%$ у третій групі та 34,4 і 30,3\% - у четвертій відповідно (рис. 1, 2).

На 7-му добу встановлено підвищення вмісту РНК та ДНК у всіх дослідних групах. Так, вміст дезоксирибонуклеїнових кислот збільшився на $17 \%$ у першій групі, 15,6 \% - в другій, 28,1\% - у третій групі та 14,8 \% в четвертій, порівняно із попереднім терміном спостереження, рибонуклеїнових кислот - на 11,7 \% у першій групі, 20,4 \% - в другій, 24,6 \% - у третій групі та 23,1\% - у четвертій.
У віддаленому терміні спостереження вміст РНК та ДНК у здорових групах щурів достовірно не відрізнявся від рівня інтактних тварин, що вказує на відновлення репаративної здатності. У щурів із ЦД 2 зниження вмісту РНК та ДНК становить 8,7 і 13,6 \% у третій та 5,6 і 10,4 \% - у четвертій групах відповідно порівняно з інтактними тваринами.

Результати, які ми отримали, доводять, що рановий процес призводить до більш інтенсивного зниження репаративної здатності дерми щурів із стрептозотоциновим цукровим діабетом, ніж у здорових тварин (табл. 2). При цьому варто відмітити, що показники репаративної здатності шкіри вірогід-

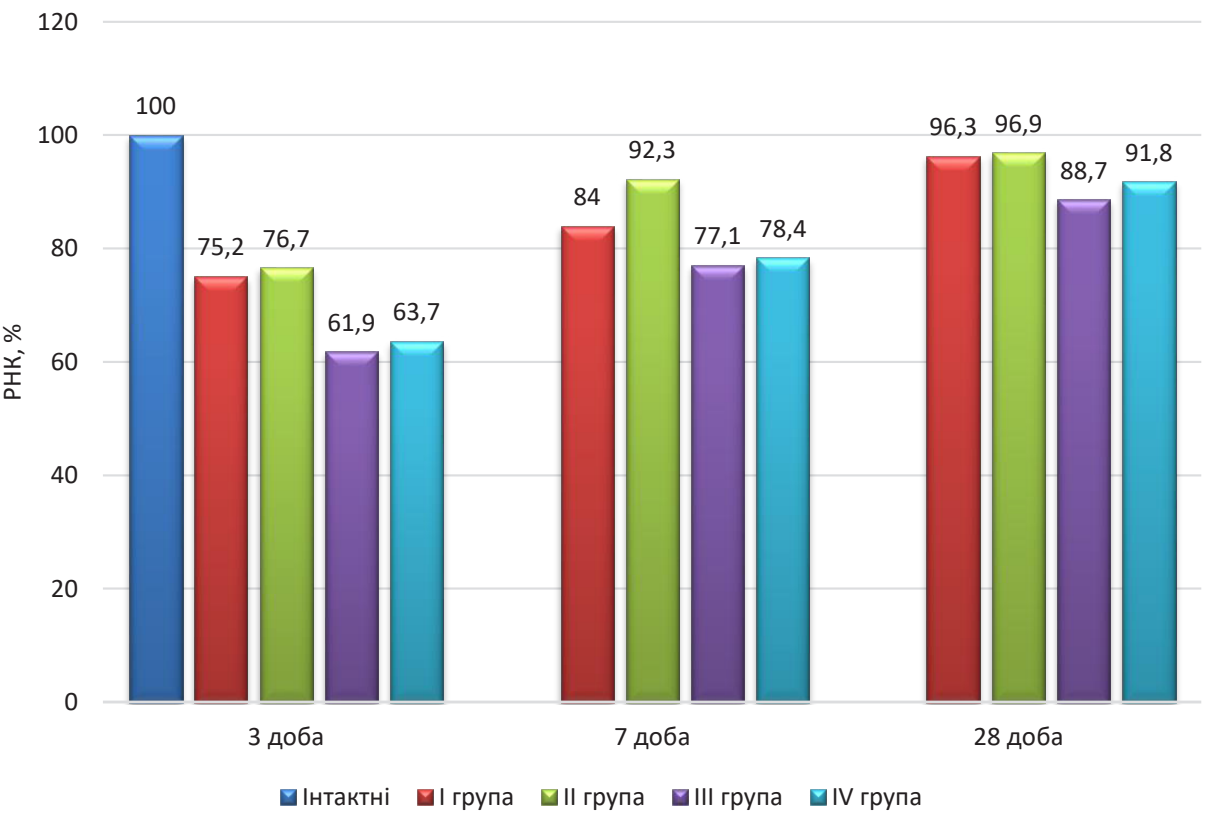

Рис. 1. Динаміка вмісту РНК у гомогенаті шкіри за умови використання ниток та шкірного клею у щурів із цукровим діабетом.

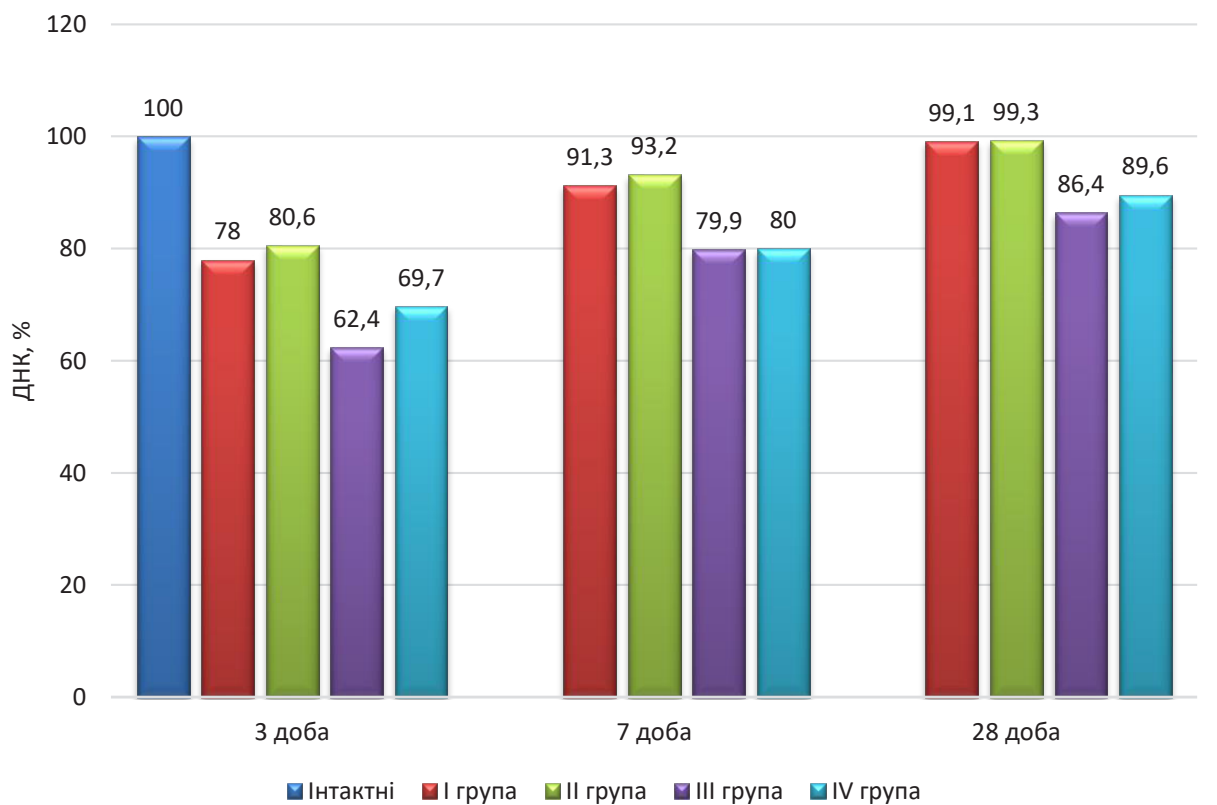

Рис. 2. Динаміка вмісту ДНК у гомогенаті шкіри за умови використання ниток та шкірного клею у щурів із цукровим діабетом. 
Таблиця 2. Динаміка показників репаративної здатності шкіри за умови використання ниток та шкірного клею у щурів

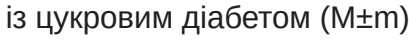

\begin{tabular}{|c|c|c|c|c|c|c|}
\hline \multirow{3}{*}{ Група } & \multicolumn{6}{|c|}{ Показник } \\
\hline & \multicolumn{3}{|c|}{ РНК, мкг/Мл } & \multicolumn{3}{|c|}{ ДНК, мкг/мл } \\
\hline & 3 доба & 7 доба & 28 доба & 3 доба & 7 доба & 28 доба \\
\hline Інтактні тварини (n=10) & \multicolumn{3}{|c|}{$29,14 \pm 0,63$} & \multicolumn{3}{|c|}{$26,12 \pm 0,24$} \\
\hline Перша група (n=10) & $\begin{array}{c}21,92 \pm 0,34 \\
{ }^{*} p \leq 0,001\end{array}$ & $\begin{array}{c}24,48 \pm 0,35 \\
{ }^{*} p \leq 0,0012\end{array}$ & $28,06 \pm 1,19$ & $\begin{array}{c}20,38 \pm 0,62 \\
* p \leq 0,001\end{array}$ & $\begin{array}{c}23,84 \pm 0,65 \\
{ }^{*} p \leq 0,01\end{array}$ & $25,89 \pm 1,13$ \\
\hline Друга група (n=10) & $\begin{array}{c}22,35 \pm 0,35 \\
* p \leq 0,001\end{array}$ & $\begin{array}{c}26,91 \pm 0,87 \\
{ }^{*} p \leq 0,1 \\
\wedge p \leq 0,001\end{array}$ & $28,25 \pm 0,95$ & $\begin{array}{c}21,06 \pm 0,27 \\
{ }^{*} p \leq 0,001\end{array}$ & $\begin{array}{c}24,35 \pm 0,50 \\
*^{*} p \leq 0,01\end{array}$ & $25,94 \pm 0,53$ \\
\hline Третя група $(\mathrm{n}=10)$ & $\begin{array}{c}18,03 \pm 0,43 \\
{ }^{*} \mathrm{p} \leq 0,001\end{array}$ & $\begin{array}{c}22,46 \pm 0,45 \\
{ }^{*} \mathrm{p} \leq 0,001\end{array}$ & $\begin{array}{c}25,86 \pm 0,62 \\
{ }^{*} p \leq 0,01\end{array}$ & $\begin{array}{c}16,29 \pm 0,89 \\
* p \leq 0,001\end{array}$ & $\begin{array}{c}20,87 \pm 0,39 \\
{ }^{*} \mathrm{p} \leq 0,001\end{array}$ & $\begin{array}{c}22,58 \pm 0,35 \\
* p \leq 0,001\end{array}$ \\
\hline Четверта група $(\mathrm{n}=10)$ & $\begin{array}{c}18,57 \pm 0,33 \\
{ }^{*} \mathrm{p} \leq 0,001\end{array}$ & $\begin{array}{c}22,86 \pm 0,41 \\
{ }^{*} \mathrm{p} \leq 0,001\end{array}$ & $\begin{array}{c}26,74 \pm 0,80 \\
{ }^{*} \mathrm{p} \leq 0,01\end{array}$ & $\begin{array}{c}18,21 \pm 0,73 \\
* \mathrm{p} \leq 0,001\end{array}$ & $\begin{array}{c}20,90 \pm 0,42 \\
{ }^{*} \mathrm{p} \leq 0,001\end{array}$ & $\begin{array}{c}23,41 \pm 0,69 \\
* \mathrm{p} \leq 0,001\end{array}$ \\
\hline
\end{tabular}

Примітки: 1) *- різниця достовірна стосовно даних інтактної групи;

2) ^ - різниця достовірна між першою та другою експериментальними групами в межах однієї доби;

3) \# - різниця достовірна між третьою та четвертою експериментальними групами в межах однієї доби.

но відрізнялися між третьою і четвертою дослідними групами на ранньому терміні спостереження, що свідчить про більш ефективне застосування шкірного клею для фрормування нормотрофрічного рубця за умов цукрового діабету порівняно із накладанням вузлових швів для оріксації країв ран.

Вивченню процесів загоєння ран, які відбуваються за умов цукрового діабету, присвячено багато досліджень, проте ми не знайшли робіт із визначенням вмісту РНК та ДНК як маркерів репаративної здатності шкіри.

\section{ВИСНОВкИ}

Отримані результати свідчать про зниження репаративної здатності шкіри, зумовленої рановим процесом у щурів з експериментальним цукровим діабетом стосовно здорових щурів при застосуванні шкірного клею (рівень РНК був нижчий на 3 добу - на 20,4 \%, на 7 добу - на 17,7 \% та, відповідно, ДНК - на 15,7 та 16,5 \%) та хірургічних ниток (рівень РНК був нижчий на 3 добу - на 21,6 \%, на 7 добу - на 9,0 \% та, відповідно, ДНК - на 20,4 та 17,7\%). При цьому застосування шкірного клею $є$ ефрективнішим для фрормування нормотрофрічного рубця за умов цукрового діабету порівняно із накладанням вузлових швів для фріксації країв ран.

гических рубцов / Е. Б. Богомолова [и др.] // Медицина, 2017. - T. 5, № 3. - C. 58-75.

6. Ogawa R. Keloid and hypertrophic scars are the result of chronic inflammation in the reticular dermis / R. Ogawa // Int. J. Mol. Sci. - 2017. - Vol. 18 (3). - P. 606.

7. Epidemiology of diabetes mellitus, pre-diabetes, undiagnosed and uncontrolled diabetes in Central Iran: results from Yazd health study / Mirzaei, M., Rahmaninan, M., Mirzaei, M. [et al.] // BMC Public Health. 2020. 20, 166. - Access mode : https://doi.org/10.1186/s12889-020-8267-y

8. Association between diabetes and cause-specific mortality in rural and urban areas of China / F. Bragg, M.V. Holmes, A. Iona [et al.] // JAMA. - 2017. - Vol. 317. P. 280-289.

9. Maffi P. The burden of diabetes: Emerging data / P. Maffi, A. Secchi // Dev. Ophthalmol. - 2017. - Vol. 60. P. 1-5.

10. Global epidemiology of diabetic foot ulceration: $A$ systematic review and meta-analysis (dagger) / P. Zhang, J. Lu, Y. Jing [et al.] // Ann. Med. -2017. - Vol. 49. - P. 106-116. DOI: $10.1080 / 07853890.2016 .1231932$ 
11. Методы клинических лабораторных исследований / под ред. В. С. Камышникова. - 4-е изд. - М. : МЕД-прессинформ, 2011. - 752 с.

12. Статистические методы в медико-биологических

\section{REFERENCES}

1. Liu J, Ren ZH, Qiang H, Wu J, Shen M, Zhang L, Lyu J. Trends in the incidence of diabetes mellitus: results from the Global Burden of Disease Study 2017 and implications for diabetes mellitus prevention. BMC Public Health. 2020;20(1): 1415. DOI: 10.1186/s12889-020-09502-X.

2. Andreeva VV, Sypkyn AM, Ehorov VY, Serheev YV, Faizullyn TR, Vasylev VS. Assessment of clinical morphological characteristics, quality of life index, psychophysical status of patients with various types of cicatricial deformities of the soft tissues of the head and neck with various methods of treatment. Trudnyy patsyent. 2020;6-7(18): 50-4. Russian.

3. Cherniakov AV. Prevention and treatment of pathological scars in surgical practice. RMZh. 2017;25(28): 2063-8. Russian.

4. Haidyna TA, Skrypkyna PA, Mynkyna OV, Halaida AO. Prevention of hypertrophic scar formation after removal of benign skin tumors. Lechebnoe delo. 2018;2: 94-9. Russian.

5. Bogomolova EB, Martusevich AK, Klemenova IA, Janin DV, Galka AG. [Application of modern methods of visualization in study and prognosing of pathological scars]. Meditsina. 2017;(3): 58-75. Russian.

6. Ogawa R. Keloid and Hypertrophic Scars Are the Result of Chronic Inflammation in the Reticular Dermis. Int J Mol Sci. 2017;18(3): 606. DOI: 10.3390/ijms18030606.

7. Mirzaei M, Rahmaninan M, Mirzaei M, Nadjarzadeh исследованиях с использованием Exel / C. Н. Лапач, А. В. Чубенко, П. Н. Бабич. - К. : Морион, 2000. - 320 с.

13. Биохимия оксидативного стресса / под ред. А. В. Шестопалова. - М. : Издательство XX, 2018. - 60 с.

A, Dehghani A. A. Epidemiology of diabetes mellitus, prediabetes, undiagnosed and uncontrolled diabetes in Central Iran: results from Yazd health study. BMC Public Health 2020;166. Available from: https://doi.org/10.1186/s12889020-8267-y

8. Bragg F, Holmes MV, Iona A, Guo Y, Du H, Chen Y, Bian Z, Yang L, et al. Association between diabetes and cause-specific mortality in rural and urban areas of China. JAMA. 2017;317(3): 280-9. DOI: 10.1001/jama.2016.19720.

9. Maffi $P$, Secchi A. The burden of diabetes: Emerging data. Dev Ophthalmol. 2017;60: 1-5. DOI: 10.1159/000459641.

10. Zhang P, Lu J, Jing Y, Tang S, Zhu D, Bi Y. Global epidemiology of diabetic foot ulceration: a systematic review and meta-analysis. Ann Med. 2017;49(2): 106-16. DOI: 10.1080/07853890.2016.1231932.

11. Kamyshnykova VS Ed. Clinical laboratory research methods. [Методы клинических лабораторных исследований] Moscow: MEDpress-inform; 2011. Russian.

12. Lapach SN, Chubenko AV, Babych PN. Statistical methods in biomedical research using Excel [Статистические методы в медико-биологических исследованиях с использованием Exel] Kyiv: Morion; 2000. Ukrainian.

13. Shestopalova AV Ed. Biochemistry of oxidative stress [Биохимия оксидативного стресса] Moscow: Yzdatelstvo KhKh; 2018. Russian. 